\title{
The Effect of Monetary Policy on the General Price Level in the Republic of Congo
}

\author{
Bambi Prince Dorian Rivel ${ }^{1} \&$ Ying Yirong $^{2}$ \\ ${ }^{1}$ Ph.D. Researcher in Finance at Shanghai University, Shanghai, China \\ ${ }^{2}$ Professor in College of Economics, Shanghai University, Shanghai, China \\ Correspondence: Bambi Prince Dorian Rivel, Ph.D. Researcher in Finance at Shanghai University, Shanghai, \\ China. E-mail: princebambi315@gmail.com
}

Received: August 15, 2020

Accepted: September 21, 2020

Online Published: September 28, 2020

doi:10.5539/ijef.v12n10p96

URL: https://doi.org/10.5539/ijef.v12n10p96

\begin{abstract}
The objective of this present work was to analyze the impact of monetary policy on the price level in the Republic of Congo over the period from 1998 to 2019. The linear regression model is the one that was used to carry out our study and the results obtained show that the monetary policy of the Bank of Central African States in the Republic of the Congo has achieved its objective of stabilizing prices, with the money supply positively influencing the price level, i.e. $33.3 \%$ of the increase in the general price level is explained by the good monetary policy of the Bank of Central African States in the Republic of Congo during the period 1998 to 2019.
\end{abstract}

Keywords: effect, monetary policy, general price level

\section{Introduction}

\subsection{Background}

Evidence of the links between monetary policy and the price level has been the subject of much economic debate to this day. This policy is implemented by a state (the government more precisely) through any banks whose main goal is to control the money supply and ensure price stability. The development of this monetary policy is, therefore, the primary objective of any government in order to ensure the social well-being of its population.

In setting up its monetary policy, banks act on the monetary base as an operational objective, with the aim of creating a stable linear relationship between the monetary base and the money supply M2, and on the other hand between the money supply M2 and the general price level. We understand that the M2 money supply, therefore, constitutes the main objective of monetary policy which makes it possible to achieve the final objective of price stability. To act on intermediate objective M2, the Bank of Central African States in the Republic of Congo sets, as part of the economic and financial program, the quantitative objective of the monetary base. The objective of monetary policy under which the Bank of Central African States in the Republic of Congo is at the head is to achieve and maintain price stability by adjusting the supply and demand for money. To do this, the Bank of Central African States in the Republic of Congo determines the control framework through which monetary policy will be implemented during the year. From this framework, he decides to what extent to reserve or relax monetary conditions.

\subsection{Problematic}

Within the framework of general economic policy, monetary policy has its own points of action to achieve the main objectives of overall economic policy. It aims to act globally on real variables of the economy through monetary variables such as money supply and demand, exchange rate, interest rate.

Thus, the real role of monetary policy is to provide the sector with the quantity of money necessary for the expansion of economic activities without generating inflationary or deflationary slippage.

However, in the context of the Republic of Congo, research on welfare through monetary policy is problematic given, on the one hand, the objectives officially assigned to monetary policy, to ensure the financing of the economic development of the country and promote domestic price stability and maintenance of the external balance of payments.

Indeed, the results of monetary policy in terms of inflation rate testify to the ineffectiveness of the transmission 
mechanisms of monetary policy on the real variables of the Congolese economy, namely price stability.

This work, therefore, aims to assess the effect of this monetary policy on the general price level in the Republic of Congo from 1998 to 2019.

\subsection{Research Question}

The research of our work is based around a question which is the following:

What is the impact of monetary policy on the general price level in the Republic of the Congo? It is to this concern that we will try to answer in our methodology section which will be done a little down in our work.

\subsection{Objective of the Study}

The objective of our research work is to analyze and address the relationship between money supply and prices to:

- analyze the evolution of the money supply and the prices.

- Determine the impact of the money supply on prices.

\subsection{Hypothesis Research}

- Monetary policy acts effectively on the general price level or the positive impact of monetary policy on the price level resulting from the good management of currency management instruments.

\section{Literature Review}

In this part of the study, we will first do a little theoretical summary of the literature review on monetary policy, then we will empirically talk about the authors who have carried out similar work on the effect of monetary policy on awards as well as the results obtained in the Central Bank of West African States and in summary the contribution of our work dealing with the issue as well as the results that were obtained. The review focuses on the methodology for evaluating the impact of monetary policy on the various inflation variables (prices).

\subsection{Theoretical Review}

In this theoretical economic review of the impact of monetary policy on prices we first have the variation in the quantity of the money supply where the policy of central banks varies according to the effects attributed to variations in the money supply: effect on the price or effect on transactions, i.e. the real sphere of the economy.

Then we have the monetarist interpretation here, for monetarist economists, an increase in the money supply $\mathrm{M}$ causes an increase in the general price level but, does not modify the real sphere. For example, a massive rise in income leads to a general rise in prices.

Then the Keynesian interpretation which does not deny a possible (but limited) rise in prices, the increase in the money supply has above all the effect of allowing a revival in the event of sluggish growth or even recession (fall in national production).

The excess of distributed currency allows:

- An increase in income which favors the purchase of consumer goods (Keynesian multiplier principle),

- An incentive for companies to invest, with economic activity picking up again (Keynesian accelerator principle).

Economists of this tendency advocate greater credit facilities (lower interest rate) and increases in income.

And finally, the choice of monetary policies or everything, therefore, depends on the causal link admitted in the equation $\mathrm{Mv}=\mathrm{PT}$.

If we consider that a change in $\mathrm{M}$ causes above all a rise in prices by leaving activity unchanged, the monetary policy of central banks must be strict: control of credit, high-interest rate.

If we consider, conversely, that a little inflation is not serious if it is controlled, monetary policy will consist of lowering the key interest rate and facilitating the granting of credit by the banks. The decision to facilitate or restrict the issuance of money ultimately lies with the central bank or the system of central banks.

\subsection{Empirical Review}

Price stability is at the heart of most central bank objectives (ECB, 2012). Therefore, the impact of exogenous shocks on monetary policy can be assessed through its effects on price stability. Empirical studies of several research works have been carried out within the Central Bank of West African States (BCEAO) since 1996, with the aim of providing an overview of the implementation of monetary policy. This empirical work has made it 
possible to identify the determining factors of price dynamic within the Union.

These are: the analysis of the contribution of monetary policy has economic growth (Blot \& Hubert, 2018), the sensitivity of economic activity to monetary and budgetary shocks in Senegal (Ndiaye, 2016). There is also work on the analysis of the impact of monetary shocks on activity and inflation (Rafiq \& Mallick, 2008; Dimitrijevic \& Lovre, 2013; Mishkin, 2009; Reynard, 2007; Bonga-Bonga \& Kabundi, 2015; Bikai \& Essiane, 2017; Ngerebo, 2016). Ngoma and Et-onomo (2019) Analysis of the Monetary Multiplier in the CEMAC Zone; Boketsu and Diwambuena (2019), "Fiscal Policy And Macroeconomic Performance; Bikai and Essiane (2018), Monetary Policy, Monetary Stability and Economic Growth. Most of these studies used relatively similar methodologies. Overall, they constructed and estimated econometric models of the auto-regressive vector (VAR) or error correction models (ECM). This model includes explanatory variables, the money supply (M2) and the interest rate for tenders on the money market.

Ndiaye (2016) analyzed the sensitivity of economic activity in Senegal to structural VAR shocks in monetary and fiscal policies. The results of the estimates that emerge there show that monetary policy fulfills its objective of stabilizing prices and remains neutral against economic activity in Senegal with a short delay in transmitting shocks. It also reveals that monetary policy reacts to shocks affecting fiscal policy in Senegal and the results of the Granger causality analysis reveal the exogenous nature of the monetary and the fiscal policy

Blot and Hubert (2018) evaluated the contribution of monetary policy to economic activity in the Euro zone, the United States and the United Kingdom from 1990 to 2018. Their analysis indicates that monetary policy has an effect significant on GDP in these six countries, with fairly long transmission times. This amounts to saying that the currency is not neutral there, because it impact in the real sector in these six economies.

In developing countries, some authors highlight the weakness of the transmission channels for monetary policy and particularly the interest rate channel, due to the weakness of the institutional framework, embryonic financial markets, banking excess liquidity, the persistence of fiduciary circulation, the weakness and instability of monetary and credit multipliers as well as the preponderance of the banking sector (Mishra et al., 2012; Mishra et al., 2016; Matata, 2019). Other authors, on the other hand, conclude with the efficiency of transmission channels in some developing countries (Saad, Mohammed, \& Zakaria, 2011; Berg et al., 2013). However, there seems to be a consensus that the interest rate channel is more efficient in countries with sufficiently developed financial markets (Mishra et al., 2012, 2016; Davoodiet al., 2013). The work of Davoodi et al. (2013) show that the use of standard statistical inferences always results in weak transmission mechanisms in developing countries.

In sub-Saharan Africa, several studies have addressed this theme, most of which confirm the weakness of the interest rate channel in the CAEMC (Central Africa Economic and Monetary Community) region (Kamgna \& Ndambendia, 2008; Bikaiet, 2015). In other words, changes in the key rate of the Bank of Central African States have little or no effect on activity and prices. None of these studies, however, looked at the impact of the interest rate on external monetary stability and mainly on foreign exchange reserve.

Other empirical studies conducted in other countries in sub-Saharan Africa have shown the impact of currency and the output gap on inflation. Barnichon and Peiris (IMF, 2008) used as an explanatory variable for inflation in sub-Saharan African countries: the output gap, currency (real currency gap: the difference between money supply and demand) and precipitation. The results of their study give elasticities of 0.28 for the output gap, 0.34 for money and -0.13 for precipitation. The elasticity of the output gap is 0.42 for countries outside the CFA zone and 0.32 for the countries of the CFA zone in the sample (Cameroon, Ivory Coast, Mali, Niger, and Senegal). The elasticity of the currency is also higher in countries outside the CFA zone (0.37) than in countries in the CFA zone (0.15). Ocran (2007), in an inflation model for Ghana, obtains an elasticity of the money supply of 0.42 . On the other hand, Kovanen (IMF, 2011), shows that the currency explains little the evolution of prices in Ghana and obtains an elasticity of the output gap with respect to inflation of 0.91 . Several studies also indicate the role of the inertia of inflation in most countries of sub-Saharan Africa and the weak capacity to explain the evolution of inflation by those of money. For the UEMOA zone, Dembo and Hounkpatin (2007) show that the current level of inflation depends strongly on the past value of price variations. Thus, the forecast error of the IHPC in UEMOA is due to $82.6 \%$ to its own innovations, $3.8 \%$ to those of the nominal effective exchange rate, and $8.8 \%$ to the evolution of import inflation and $4.8 \%$ to changes in the money supply

\section{Methodology}

In this work, we propose to study the effect of monetary policy on prices in the Republic of Congo. The objectives set being to analyze the evolution of money supply and prices as well as to determine the impact of money supply on prices, two approaches were adopted: a descriptive approach and an econometric approach. 
The descriptive approach will allow us to achieve our first objective, which is to make a comparative analysis ofthe evolution of money supply and prices in the Republic of Congo. This analysis has been illustrated from the various figures to help usunderstand the relationship between money supply and prices between 1998 and 2019 .

The second objective will be achieved by analyzing the impact of monetary policy on prices between 1998 and 2019; the econometric approach has been adopted.

\subsection{Presentation of the Variables and the Model}

For our study, we propose the following variables based on data available from 1998 to 2019 in order to explain the impact of monetary policy on prices in the Republic of Congo. We will, therefore, show the relationship between money supply and prices. In order to show this relationship, our model will be made up of the following variables: Consumer Price Index (CPI), money supply (M2), GDP growth (annual \%), Imports of goods and services (IGS), Official exchange rate (OER), Inflation consumer prices (ICP)

\subsection{Linear Regression Equation}

Based on the variables mentioned, our economic model is based on the estimation of common linear least squares (OLS) multiple linear regression model which takes the following form:

$$
\log (C P I)=\beta_{0}+\beta_{1} \log (M 2)+\beta_{2} \log (I C P)+\beta_{3} \log (O E R)+\beta_{4} \log (G D P)+\beta_{5} \log (I G S)+\varepsilon_{i t}
$$

With $\beta_{0}$ the constant and $\varepsilon_{i t}$ : the error term $\beta_{1}=\beta_{5}$ Coefficient of independent variables.

$\log (\mathrm{CPI})=$ Logarithm of Consumer Price Index;

$\log (\mathrm{M} 2)=$ Logarithm of Money supply;

$\log (\mathrm{ICP})=$ Logarithm of Inflation consumer price;

$\log (\mathrm{OER})=$ Logarithm of Official exchange rate;

$\log ($ GDP growth $)=$ Logarithm of Gross domestic product;

$\log ($ IGS $)=$ Logarithm of Imports goods and services.

\subsection{Data Source and Processing}

The data used for the estimation come from the World Bank (WB) and cover a period from 1998 to 2019. These data will be processed using Microsoft Excel 2007 and IBM SPSS Statistics software.

\subsection{Empirical Analysis Results of the Descriptive Approach}

This section allows us to make a descriptive analysis of the various trends in the money supply, consumer price index and inflation consumer price variables from the period 1998 to 2019.

The broad money supply grew by $12 \%$ year-on-year, which however translated into an increase in the level of reserves at the Bank of Central African States rather than more loans to the Central African States economy. In September, credit to the private sector was down about $91 / 2 \%$ (year-on-year).

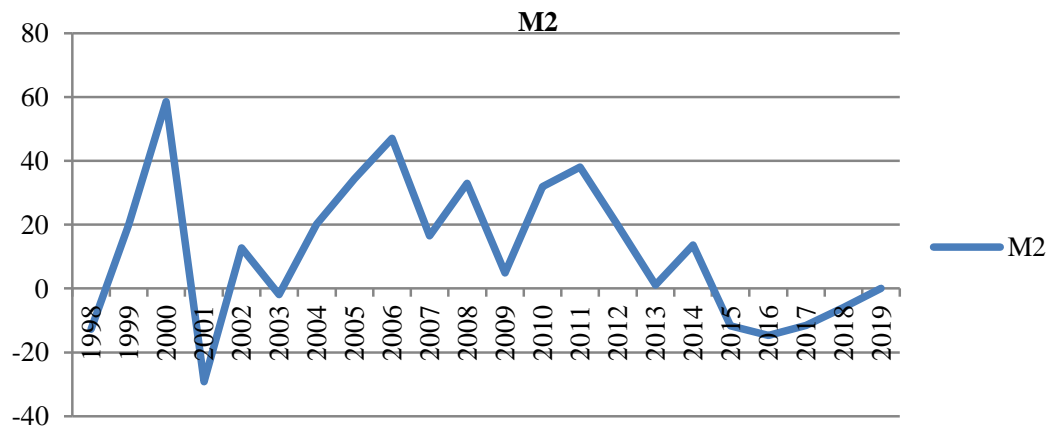

Figure 1. M2 evolution from 1998 to 2019

Source: Author World Bank data with Excel 2007.

We notice a considerable evolution of the consumer price index from 1998 to 2019 with an annual average of $77.74 \%$ recorded. The highest value is $124.74 \%$ in 2019 and the lowest $73.47 \%$ is in 1998 . Based on the available data, we can estimate that in 2025 the value should oscillate around 138 . This forecast has a very high level of reliability since the available values have a linear structure (correlation coefficient $=0.99$ and coefficient of determination $=0.98$ ). 
CPI

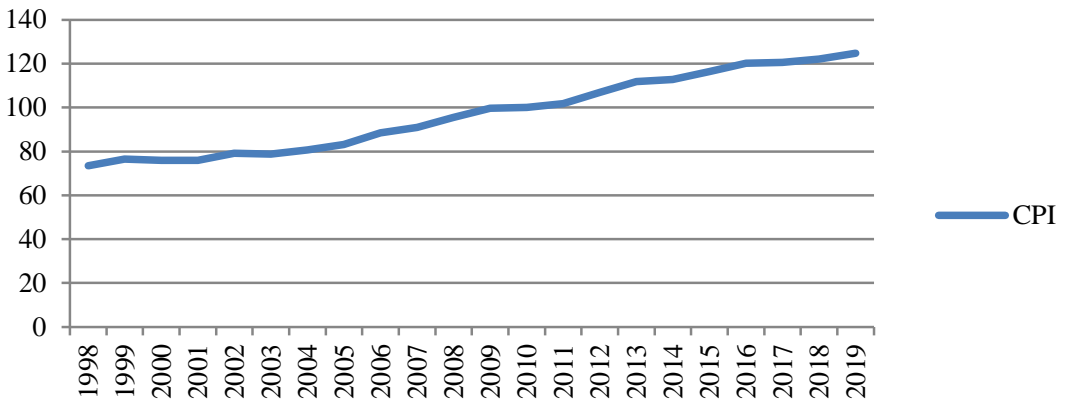

Figure 2. Consumer price index $(2010=100)$ evolution from 1998 to 2019

Source: Author World Bank data with Excel 2007.

Headline inflation as shown on the graph remained subdued at $1.8 \%$ yoy at the end of October 2019 and is expected to remain around $2 \%$ by the end of the year. This is explained by the prices of foodstuffs which have fallen by around $0.3 \%$ in the last 12 months,

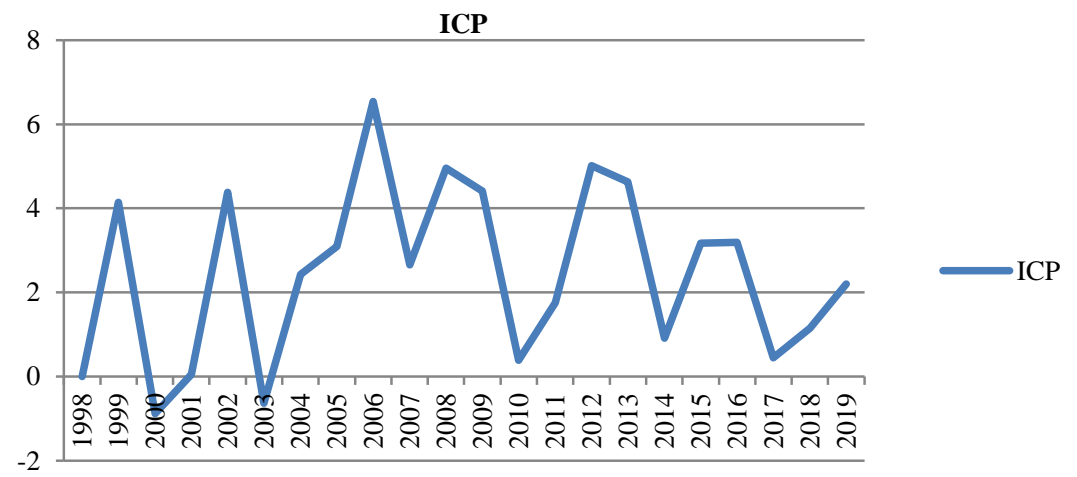

Figure 3. Inflation consumer price evolution from 1998 to 2019

Source: Author World Bank data with Excel 2007.

\section{Econometric Results}

This section presents the econometric and economic results of this study. It assesses the impact of monetary policy in the Republic of Congo. We will present the results obtained during the regression of our data on the SPSS software ranging from 1998 to 2019.

4.1 Presentation and Interpretation of Tables' Results Obtained During the Regression of Our Data on the SPSS Statistic Software

In this subsection we will comment and interpret the results obtained as far as possible as they appear while taking into account what was mentioned a little earlier in the literature review in order to see if the monetary policy has an impact or not on general price level in the Republic of the Congo

Table 1. Observation of the variables result

\begin{tabular}{|c|c|c|c|}
\hline \multicolumn{4}{|c|}{ Variables Entered/Removed $^{\mathrm{a}}$} \\
\hline Model & Variables Entered & Variables Removed & Method \\
\hline 1 & GDP growth, ICP,IGS, OER, M2 ${ }^{\mathrm{b}}$ & 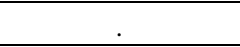 & Enter \\
\hline \multicolumn{4}{|c|}{ a. Dependent Variable: CPI } \\
\hline b. All reque & ntered. & & \\
\hline
\end{tabular}

We can indeed notice in this table 1 that all the variables mentioned and used in our formula have all been taken into account to perform our linear regression on SPSS statistics software. This confirms that we have the variables GDP growth, ICP, IGS, OER, M2 as independent and CPI as dependent variable. 


\subsection{Correlation Matrix Results}

There are two positive correlations between CPI and IGS and ICP and three negative correlations between CPI and M2 and OER and GDP growth.

By continuing to argument IGS and ICP are positively correlated and significant at the 0.05 level. Which means that IGS and ICP contribute respectively at $2.09 \%$ and $1.17 \%$ on CPI in republic of Congo.

The M2, OER and GDP growth as for them they have an inverse relationship which mean the more M2, OER and GDP growth increase, ICP decreases.

Let's continue to look at the analysis of our regression tests in the next table call Durbin-Watson table in order to test the conformity of the factors that affect ICP in republic of Congo.

Table 2. Pearson correlation matrix regression results from 1998 to 2019

\begin{tabular}{llcccccc}
\hline \multicolumn{1}{c}{} & \multicolumn{9}{c}{ correlation $^{\mathbf{a}}$} & & & \\
\hline Pearson & & CPI & M2 & ICP & OER & IGS & GDP growth \\
Correlation & CPI & 1 & -.307 & .117 & -.351 & .209 & -.286 \\
& M2 & -.307 & 1 & .234 & -.288 & -.420 & .513 \\
& ICP & .117 & .234 & 1 & -.379 & .005 & .031 \\
& OER & -.351 & -.288 & -.379 & 1 & .010 & -.173 \\
& IGS & .209 & -.420 & .005 & .010 & 1 & -.230 \\
& GDP growth & -.286 & .513 & .031 & -.173 & -.230 & 1 \\
& CPI &. & .082 & .301 & .055 & .176 & .099 \\
& M2 & .082 &. & .147 & .097 & .026 & .007 \\
& ICP & .301 & .147 &. & .041 & .492 & .446 \\
& OER & .055 & .097 & .041 &. & .483 & .221 \\
& IGS & .176 & .026 & .492 & .483 &. & .152 \\
& GDP growth & .099 & .007 & .446 & .221 & .152 &. \\
\hline
\end{tabular}

a. $* * *$ Correlation is significant at the 0.05 level (2-tailed)

b. Listwise $\mathrm{N}=22$

Source: Author from SPSS Statistics Result.

\subsection{Durbin-Watson Result}

Table 3. Durbin-Watson result model summary

\begin{tabular}{|c|c|c|c|c|c|c|c|c|c|c|}
\hline \multicolumn{11}{|c|}{ Model Summary ${ }^{\text {b }}$} \\
\hline \multirow[t]{2}{*}{ Model } & \multirow[t]{2}{*}{$\mathrm{R}$} & \multirow[t]{2}{*}{ R Square } & \multirow{2}{*}{$\begin{array}{l}\text { Adjusted } \\
\text { R Square }\end{array}$} & \multirow{2}{*}{$\begin{array}{c}\text { Std. Error of } \\
\text { Estimation }\end{array}$} & \multicolumn{5}{|c|}{ Change in statistics } & \multirow{2}{*}{$\begin{array}{l}\text { Durbin- } \\
\text { Watson }\end{array}$} \\
\hline & & & & & Variation of R Square & Variation of $\mathrm{F}$ & dd11 & $\mathrm{dd} 12$ & Sig. Variation of $F$ & \\
\hline 1 & $.577^{\mathrm{a}}$ & .333 & .124 & 16.5493790331 & .333 & 1.594 & 5 & 16 & .218 & .692 \\
\hline \multicolumn{11}{|c|}{ a. Predicted values: (constant), GDP growth, ICP, IGS, OER, M2 } \\
\hline
\end{tabular}

Source: Author from SPSS Statistics Result.

In the Durbin-Watson model summary result, the multiple linear regression method was used to perform the Durbin-Watson test, which consists in verifying the error independence hypothesis. What we are going to focus the most here and to explain in the table 3 is Durbin-Watson and the $R^{2}$.

- Concerning Durbin-Watson, as we know it already in its definition the Durbin Watson (DW) statistic is a test for autocorrelation in the residuals from a statistical regression analysis. He will always have a value between 0 and 4. A value of 2.0 means that there is no autocorrelation detected in the sample. Values from 0 to less than 2 indicate positive autocorrelation and values from 2 to 4 indicate negative autocorrelation.

In our study, the result of Durbin-Watson value is 0.692 , which indicates that the assumption that the error terms are independent has been fulfilled.

- The $R^{2}$ as for him in its definition is the measure of the amount of variance in dependent variable that the independent variables account for when taken as a group. Its measurement is not based on how much an individual predictor or a given individual variable represents, but only when we take them all as a group, this model summary table says overall, the regression model, which is what is referred to sometimes as a model, 
these five (5) predictors predicting CPI that overall model account for $33.3 \%$ of the variance. And as we can see in the table 3 the amount of the $R^{2}$ is 0.333 which is equal to 33.3, which simply means taken as a set the predictor M2, ICP, OER, IGS, and GDP growth account of 33.3\% of the variance in CPI.

\subsection{Variance Analysis Result (ANOVA)}

The ANOVA table is the test to know if this R Squared is significantly greater than 0 . It indicates the general probability of our model. In the ANOVA table, the result shows that there is a significant relationship between the five (5) predictor variables and the dependent variable at the 0.05 level of significance, where $p<0.05$.

And if we look at our table here we find that in the column labeled "Sig" that $p$-value $=0.218$ is less than 0.5 which means that the regression of our test is significant, $R^{2}$ is significant at 0 .

The p-value being less than 0.5 we know that the value of $R^{2}$ is significant and greater than 0 and this means that our independent variables are capable of taking into account a significant amount of variance in CPI. So in other words, the regression model is significant.

Table 4. ANOVA

\begin{tabular}{llccccc}
\hline \multicolumn{7}{c}{ ANOVA $^{\mathrm{a}}$} \\
\hline Model & & Sum of Squares & df & Mean Square & F & Sig. \\
\hline \multirow{3}{*}{1} & Regression & 2182.998 & 5 & 436.600 & 1.594 & $.218^{\text {b }}$ \\
& Residual & 4382.111 & 16 & 273.882 & & \\
& Total & 6565.109 & 21 & & & \\
\hline
\end{tabular}

a. Dependent Variable: CPI

b. Predicted values: (constant), GDP growth, ICP, IGS, OER, M2

Source: Author from SPSS Statistics Result.

\subsubsection{ANOVA Table (Test With Alpha $=0.5$ )}

The regression model is globally significant and here we have F (5 and 16) for the regression and residual = $1.594, \mathrm{p}<0.218, \mathrm{R}$ square $=33.3$.

This is to tell us that our regression analysis is statistically significant when I take these five(5) predictors together as a group, they predict CPI significantly.

\subsection{Coefficient Analysis Result for the Dependent Variable CPI}

Table 5. Coefficient regression result analysis for the dependent variable CPI

\begin{tabular}{|c|c|c|c|c|c|c|c|c|}
\hline \multicolumn{9}{|c|}{ Coefficients $^{\mathrm{a}}$} \\
\hline \multirow{2}{*}{\multicolumn{2}{|c|}{ Model }} & \multicolumn{2}{|c|}{ Unstandardized coefficients } & \multirow{2}{*}{$\begin{array}{c}\text { Standardized coefficients } \\
\text { Beta } \\
\end{array}$} & \multirow[t]{2}{*}{$\mathrm{T}$} & \multirow[t]{2}{*}{ Sig. } & \multicolumn{2}{|c|}{$95.0 \% \%$ confidence intervals for B } \\
\hline & & $\mathrm{B}$ & Std Error & & & & Lower bound & Upper limit \\
\hline \multirow[t]{6}{*}{1} & (Constante) & 159.507 & 37.480 & & 4.256 & .001 & 80.053 & 238.961 \\
\hline & M2 & -.269 & .213 & -.342 & -1.265 & .224 & -.719 & .182 \\
\hline & ICP & .203 & 1.910 & .024 & .106 & .917 & -3.845 & 4.251 \\
\hline & OER & -.105 & .051 & -.473 & -2.073 & .055 & -.213 & .002 \\
\hline & IGS & .034 & .291 & .027 & .117 & .908 & -.582 & .650 \\
\hline & GDP growth & -.935 & 1.201 & -.187 & -.779 & .447 & -3.481 & 1.610 \\
\hline
\end{tabular}

Note. Dependent variable: CPI.

Source: Author from SPSS Statistics Result.

Opposite to the first two summary model and ANOVA which examine the regression analysis as a whole, where the variables are taken as a whole, the coefficients on the other hand examines each of the predictors or variables individually. Basically we can say it is the probability of each of the variables that we used in the model to make our regression also called p-value. And what we are doing here is that we are going to look at each of our predictors and we want to zero out on it the Sig column, which are again the p-values of each of the tests. However, in this analysis, our constant has absolutely no importance. We will just focus on the five (5) p-values of M2, ICP, OER, IGS, and GDP growth. So we will evaluate each of these tests at an alpha of 0.5 by looking at it we see that:

- M2 with a negative amount of -0.269 it is significant on CPI because its p-value $=0.224$ it mean that M2 have a big influence in CPI, he explained a significant amount of unique variance in CPI. 
- ICP has a positive amount of 0.203 but is not significant on CPI because its p-value $=0.917$ which is greater than 0.5 which is our alpha threshold. It simply mean that ICP don't have a big influence on CPI.

- OER has a negative amount of -0.105 is significant on CPI because its p-value $=0.055$; which mean that OER have a big influence in CPI and also explained a significant amount of unique variance in CPI.

- IGS has a positive amount of 0.034 and is not significant on CPI because its p-value $=0.908$ which is greater than 0.5 which is our alpha threshold that mean IGS also does not have a big influence on CPI.

- GDP growth has a negative amount of -0.935 and is significant on CPI because its p-value $=0.447$ which also mean that GDP Growth have a big influence in CPI and also explained a significant amount of unique variance in CPI.

\section{Conclusion}

Our present research work aimed to assess the effect of monetary policy on the general price level in the Republic of Congo from 1998 to 2019. After analysis and interpretation of the results via the linear regression which was carried out, we observe that our assumptions have been confirmed. Our assumptions were based on the idea that the monetary policy of the Congo's central bank (BCC) acts effectively on the general price level. The results of the calculation carried out through the SPSS software show that the monetary policy of the Bank of Central African States in the Republic of Congo has a positive impact on the general price level, i.e. 33.3\% of the increase in the general price level is explained by the good monetary policy of the Bank of Central African States in the Republic of Congo during the period 1998 to 2019.

It emerges from this study, the effectiveness of the instruments of monetary policy put in place by the monetary authority which is the bank of the central African states of the Republic of Congo in order to control the general increase in the level of prices

\section{References}

Barnichon, R., \& Peiris, S. J. (2008). Sources Of Inflation in Sub-Saharan Africa. Journal of African Economies. https://doi.org/10.1093/jae/ejn002

Berg, A., Charry, L., \& Portillo, R. (2013). The Monetary Transmission Mechanism In The Tropics: A narrative approach. https://doi.org/10.5089/9781484398135.001

Bikai, J. L., \& Kenkouo, G. A. (2015). Analysis And Evaluation Of The Transmission Channels Of Monetary Policy In CEMAC: A SVAR and SPVAR Approach. BEAC Working Paper No. 2/2015.BEAC. Retrieved from https://mpra.ub.uni-muenchen.de/78227/1/MPRA_paper_78227.pdf

Bikai, J. L., Batoumen, M. H., \& Fossouo, K. A. (2016). Determinants of Inflation in CEMAC: Le Rôle De La Monnaie. BEAC Working Paper No. BWP 05/16. Yaoundé: BEAC. Retrieved from https://mpra.ub.uni-muenchen.de/89111/1/MPRA_paper_89111.pdf

Bikai, J., \& Essiane, D. (2018). Monetary Policy, Monetary Stability and Economic Growth, In CEMAC: A Bayesian SVAR Approach. BEAC Working Paper No. BWP 05/18. Yaoundé: BEAC. https://doi.org/10.13140/RG.2.2.24527.59048

Blot, C., \& Hubert, P. (2018). An Analysis of the Contribution of Monetary Policy to Economic Growth. Revue de L'OFCE, 159. https://doi.org/10.3917/reof.159.0231

Boketsu, J., \& Diwambuena, J. (2019). Fiscal Policy And Macroeconomic Performance in the Democratic Republic Of Congo. Congo Challenge Review, 1(2), 202-2035.

Davoodi, H. R., Dixit, S., \& Pinter, G. (2013). Monetary Transmission Mechanism In The East African Community: An Empirical Investigation. IMF Working Paper No.WP/13/39. International Monetary Fund. https://doi.org/10.5089/9781475530575.001

Dimitrijevic, B., \& Louvre, I. (2013). Essay On Monetary Policy And Economic Growth? Journal of Central Banking Theory And Practice, 1, 111-138. Retrieved from http://www.cbcg.me/repec/cbk/journl/vol2no1-6.pdf

ECB. (2011). ECB Bank Lending Surveys for October 2011 and January 2012. Retrieved from https://www.ecb.europa.eu/stats/ecb_surveys/bank_lending_survey/pdf/ecb.blssurvey2011q4.en.pdf

ECB. (2012). ECB Staff Macroeconomic Projections for the Euro Area. Monthly Bulletin, European Central Bank. Retrieved from https://www.ecb.europa.eu/pub/pdf/other/ecbstaffprojections201203en.pdf

Kovanen, A. (2011). Does Money Matter for Inflation in Ghana? IMF Working Paper. 
https://doi.org/10.5089/9781463925291.001

Mishra, P., \& Montiel, P. (2013). How Effective Is Monetary Policy In Low-Income Countries? A Survey of the Empirical Evidence. Economic Systems, 37, 187-216. https://doi.org/10.1016/j.ecosys.2012.12.001

Mishra, P., Montiel, P., \& Sengupta, R. (2016). Monetary Transmission In Developing Countries: Evidence From Indiall. IMF Working Paper No.WP/16/167. International Monetary Fund. https://doi.org/10.5089/9781475523966.001

Mishra, P., Montiel, P., \& Spilimbergo, A. (2013). Monetary Transmission in Low-Income Countries: Effectiveness And Policy Implications. IMF Economic Review, 60, 270-302. https://doi.org/10.1057/imfer.2012.7

Ndiaye, C. T. (2016). Sensitivity of Economic Activity to Monetary and Fiscal Shocks in Senegal, Laboratoire D'économie D'ORLEANS (LEO). Retrieved fromhttps://mpra.ub.uni-muenchen.de/id/eprint/101255

Ngoma, B., \& Et-onomo, B. (2019). Analysis of the Monetary Multiplier in the CEMAC Zone: Evolution, Stability And Forecast. BEAC Working Paper. Retrieved from https://www.researchgate.net/publication/331951711

Ocran, M. K. (2007). A Modeling of Ghana's Inflation Experience: 1960-2003. AERC Research Paper. Retrieved from https://aercafrica.org/wp-content/uploads/2018/07/RP169.pdf

Rafiq, M. S., \& Mallick, S. K. (2008). The Effect of Monetary Policy on Output in EMU3 A Sign Restriction Approach? Journal of Macroeconomics. https://doi.org/10.1016/j.jmacro.2007.12.003

Savin, N. E., \& White, K. J. (1977). The Durbin-Watson test for serial correlation with extreme sample sizes or many regressors. Econometrica, 45. https://doi.org/10.2307/1914122

\section{Appendix}

\section{Data base for estimation}

\begin{tabular}{lllllll}
\hline Years & M2 & CPI & ICP & OER & IGS & GDP growth \\
\hline 1998 & $-12,78290919$ & 73,4672025 & 0 & 589,951775 & 72,62403269 & 3,73755277 \\
1999 & 19,8714159 & 76,5107072 & 4,142671373 & 615,473349 & 59,10411923 & $-2,582199357$ \\
2000 & 58,52195397 & 75,8358893 & $-0,881991517$ & 710,207977 & 43,61273719 & 7,575980392 \\
2001 & $-29,24524351$ & 75,8783498 & 0,055989922 & 732,397693 & 53,31245423 & 3,8026019 \\
2002 & 12,67805123 & 79,2008804 & 4,378759718 & 693,713226 & 53,93964559 & 4,581870061 \\
2003 & $-1,936173805$ & 78,7004536 & $-0,631844987$ & 579,897426 & 76,04941174 & 0,813264075 \\
2004 & 20,1010159 & 80,6126905 & 2,42976608 & 527,338032 & 50,83840588 & 3,476631623 \\
2005 & 34,37195343 & 83,1072422 & 3,094490115 & 527,258363 & 54,5053942 & 7,755758978 \\
2006 & 47,07537865 & 88,5406641 & 6,537843953 & 522,425625 & 65,61996668 & 6,235997013 \\
2007 & 16,564433 & 90,8911056 & 2,654646451 & 478,633718 & 53,52311323 & $-1,58222275$ \\
2008 & 32,96816235 & 95,3981692 & 4,95875092 & 446,000041 & 47,0024926 & 5,572233235 \\
2009 & 4,909264778 & 99,6100019 & 4,415003748 & 470,293423 & 50,20542228 & 7,468942484 \\
2021 & 31,95524279 & 100 & 0,391525011 & 494,794262 & 54,69792897 & 8,751601459 \\
2011 & 38,0524976 & 101,759587 & 1,759587043 & 471,248626 & 57,83572831 & 3,420665681 \\
2012 & 19,83495318 & 106,857933 & 5,010187731 & 510,556338 & 60,32926753 & 3,799971313 \\
2013 & 1,054921978 & 111,807183 & 4,631616197 & 493,899624 & 66,0719813 & 3,440705249 \\
2014 & 13,65567434 & 112,82702 & 0,912139545 & 493,75733 & 70,25263291 & 6,779916158 \\
2015 & $-11,708263$ & 116,402619 & 3,169097968 & 591,211698 & 96,37029556 & 2,646485877 \\
2016 & $-14,73173559$ & 120,116517 & 3,190561797 & 592,605615 & 85,67662474 & $-2,800018788$ \\
2017 & $-11,5569235$ & 120,657118 & 0,450063823 & 580,65675 & 62,9177991 & $-1,801001225$ \\
2018 & $-6,009807106$ & 122,048027 & 1,152778964 & 555,446458 & 57,46375241 & 1,6 \\
2019 & 0 & 124,740496 & 2,206073058 & 585,911013 & 34,80312905 & $-0,899999998$ \\
\hline
\end{tabular}

Source: Author World Bank.

\section{Copyrights}

Copyright for this article is retained by the author(s), with first publication rights granted to the journal.

This is an open-access article distributed under the terms and conditions of the Creative Commons Attribution license (http://creativecommons.org/licenses/by/4.0/). 